\title{
The Criminal Law Policies in Law Enforcement of Local Regulations on Smoking-Free Areas
}

\section{Dian Pramythasari Utamawati ${ }^{*}$ and Gunarto ${ }^{* *}$}

*) Student Master of Law, Faculty of Law, Universitas Islam Sultan Agung Semarang and DPRD's Secretariat of Cirebon, E-mail: dianpramytha9312@gmail.com ${ }^{* *}$ Lecturer of Faculty of Law, Universitas Islam Sultan Agung Semarang

\begin{abstract}
.
The purpose of this research is as follows: To know and analyze criminal law policy in enforcing local regulations on No Smoking Areas. To find out and analyze the implementation in enforcement of local regulations on No Smoking Areas. To find out and analyzebarriers to implementing the enforcement of local regulations on No Smoking Areas and their solutions. This study uses an empirical juridical approach, with descriptive analytical research specifications. The data used in this study are secondary data obtained through library research and primary data which are then analyzed qualitatively. The result of this research is that the purpose of this policy is to provide human rights for citizens to obtain a clean, healthy and safe environment. Implementation in the Enforcement of Regional Regulations on No Smoking Areas is still not optimal as seen from the previous discussion there are still individuals or employees who have not complied with the regional regulations for no smoking areas. Barriers: $a$. A designated smoking area that is rarely used. $b$. Lack of employee awareness of comfort and health. c. There are still employees who have not complied with these regulations. The solution: a. The person in charge again provides outreach on the No Smoking Area Regional Regulation to employees. b. Provide sanctions in the form of fines. c. Improve communication about smoking rooms. d. Raise employees' awareness of the benefits of smoke-free areas.
\end{abstract}

Keywords: Criminal Law Policies; Enforcement; Regional Regulations; No Smoking Areas.

\section{Introduction}

The formation of regional regulations (Perda) to encourage and optimize regional development can only be realized if the formation of regional regulations is supported by means and methods in accordance with statutory regulations, regional needs and local wisdom in earnest. Regarding legislation or the manufacture of statutory products, no country can ignore it, especially Indonesia, which claims to be a state based on law. As a rule of law, the government has the task of carrying out public welfare, where the state or government intervenes in taking care of the people's welfare. This becomes an absolute or inevitable in the welfare state law. ${ }^{1}$

\footnotetext{
${ }^{1}$ Iwan Sulistiyo, Widayati, Sri Kusriyah, Implementation of the Principle of Openness in the Process of Forming Regional Regulations in the Context of Regional Autonomy in Kendal Regency, Jurnal Daulat Hukum Vol. 1. No. March 1, 2018 ISSN: 2614-560X
} 
Criminal law policy is an integral part of social policy, law enforcement policy, and criminal policy, which includes rational efforts in tackling crime, to achieve the nation's goals, namely protection of society and welfare of society. ${ }^{2}$

In criminal law politics, it is not easy to determine an act as a criminal act and must first go through several in-depth review processes. ${ }^{3}$ Apart from the study of acts from a criminological point of view, it must also consider the objectives of the criminal law itself, the determination of undesirable acts, the comparison between the means and the results and the capabilities of the law enforcement agencies. ${ }^{4}$

Further regulations regarding KTR including sanctions for violations of KTR in provinces and districts/cities are regulated by respective regional regulations, sanctions for individuals in the form of minor criminal sanctions, while for legal entities or business entities are subject to administrative sanctions and/or fines. ${ }^{5}$

Retribution is a source of local revenue. Retribution is a regional tax as payment for regional service assistance or certain special permits granted and/or granted by the Regional Government for personal or corporate interests. Retribution is very important to support local revenue, but in practice there are many factors that make it less than optimal. ${ }^{6}$

Smoking is an activity that has become entrenched in Indonesian society. Both parents and underage children are dependent on or addicted to smoking, this is even commonplace we find in everyday life everywhere and at all times. Smoking is very dangerous and damaging to health for both active smokers and those around the smoker, because cigarettes contain substances that are very harmful to health. For passive smokers, inhaling secondhand smoke is more dangerous than smoking cigarettes alone because $85.4 \%$ of active smokers smoke in the home with family members, thus threatening the safety of environmental health. Even the dangers that must be borne by passive smokers are three times the dangers of active smokers. ${ }^{7}$

To regulate order and comfort and the Government to enact Regional Regulations and create many conflicts in society. Juridical Analysis of Community Participation in the Formation of Regional Regulations. Legislation. Article 96 "The public has the right to provide responses verbally and/or in writing, which can be done through hearings, work visits, socialization and/or, seminars, workshops and/or discussions. In the Formation of Regional Regulations, community participation has not been maximized. The obstacles faced are the lack of public interest in participating, the Government is considered to have insufficient public aspirations to be overcome by it, providing an understanding of the importance of

\footnotetext{
2 https://budi399.wordpress.com/2019/04/01/keb Policy-hukum-pidana/, accessed on 6 October 2020, 19.37 WIB

3 Timbul Mangaratua Simbolon, Gunarto, Umar Ma'ruf, Criminal Law Policy Against the Crime of Defamation or Defamation Through the Internet in Indonesia as Cybercrime, Jurnal Daulat Hukum Vol. 1. No. 1 March 2018 ISSN: 2614-560X, Sultan Agung Islamic University

4 Sudarto. (1983). Hukum Pidana dan Perkembangan Masyarakat. Bandung: Sinar Baru. p. 12

${ }^{5}$ Article 6 Joint Regulation 188 of 2011

${ }^{6}$ Amin Purnawan,Muhammad Yanuar Ilham, Implementation Of Withdrawal Of Retribution Based On Kudus Regency Regulation No. 14 of 2012 On The Market Services Retribution In Kliwon Market Kudus, Jurnal Daulat Hukum Vol 2, No 2 (2019): June 2019 Sultan Agung Islamic University

7 Sofianto, Hufron. (2010). Mengenai Budaya Merokok Bagi Kesehatan. Bogor: Horizon. p. 3
} 
community participation in the formation of Regional Regulations, maximizing the socialization of regulations and thirdly accommodating all community aspirations. ${ }^{8}$

The purpose of this research is as follows: To know and analyze criminal law policy in enforcing local regulations on No Smoking Areas. To find out and analyze the implementation inenforcement of local regulations on No Smoking Areas. To find out and analyze barriers to implementing the enforcement of local regulations on No Smoking Areas and their solutions.

\section{Research methods}

The research approach method that researchers use is juridical empirical law (socio-legal research). ${ }^{9}$ This research is a descriptive analytical research based on its nature. The data used in this study are secondary data obtained through library research and primary data which are then analyzed qualitatively.

\section{Result and Discussion}

\subsection{Criminal Law Policies in Enforcement of Regional Regulations Number Regarding No-Smoking Areas}

Safeguarding cigarettes for health needs to be done by providing information about the content of nicotine and tar content on each cigarette, inclusion of warnings on labels, regulation of cigarette production and sales, cigarette advertising and promotion. In addition, it is necessary to establish a smoking-free area in health service facilities, places for teaching and learning, where children play, places of worship, public transportation and other places. In an effort to tackle the dangers caused by smoking and to make it more effective, efficient and integrated, a Regional Regulation on No Smoking Areas is needed.

Perda is able to create efficiency and effectiveness of government. Reduction and demotion of office structures will certainly have an impact on improving the quality of bureaucratic performance in providing public services that are more effective and efficient in implementing large areas. autonomy, real and responsible. Thus the concept of streamlining the structure of the structuring and management of the bureaucratic apparatus becomes linear simultaneously. ${ }^{10}$

No Smoking Area (KTR) One of the other tobacco control policies is the implementation of PERDA policies. KTR is a sterilization area from activities related to or causing air pollution. As a form of effort to sterilize smoking and all types related to it, from production to sales. The local government in this case wants to create a healthy area from pollution, including cigarette smoke. Therefore, the government through its KTR program is stipulated in regulations so that it can be applied and implemented and supported by all levels of society, from

\footnotetext{
8 Rakhmat Bowo Suharto, Amin Syarifudin, Analysis Juridical Public Participation Formation of Regional Regulation No. 3 of 2017 on The Implementation of The Business Entertainment In Wonosobo Regency, Jurnal Daulat Hukum, Vol 2, No 1 (2019): March 2019, Unissula

${ }_{9}^{9}$ Ali, Zainudin. (2009). Metode Penelitian Hukum. Jakarta: Sinar Grafika. p. 105

${ }^{10}$ Ahmad Faqih, Wonosobo Regulation No. 3 of 2014 on Regarding Regional Organizations to Achieve Good Governance, Jurnal Daulat Hukum Vol 1, No 2 (2018): June 2018, Universitas Islam Sultan Agung
} 
government officials to the ordinary public. The implementation and application of the KTR policy is meaningless if it is not supported by all levels of society. The most important challenge in implementing the PERDA KTR lies in each of the elements. That is how the community responds and welcomes the policy with full awareness and a desire to comply with it. The provisions for places that are included in the KTR list are public areas such as in public transportation, educational/school environments as well as other types of learning spaces, and other places that have been regulated in the provisions of the PERDA KTR.

The policy on the use of criminal sanctions in the Regional Regulation is essentially part of the politics of criminal law or criminal law policy (penal policy). Carrying out the politics of criminal law means holding elections to achieve the best statutory results in terms of meeting the requirements of justice and efficiency. Implementing criminal law politics also has the meaning of an effort to realize criminal laws and regulations in accordance with the circumstances and situations at one time and for the future. ${ }^{11}$ Thus, the criminal law policy contains the meaning of "how to seek or make and formulate a good criminal law. ${ }^{12}$

The Criminal Law Policy in Enforcement of Regional Regulations on No Smoking Areas in the KTR PERDA means that the purpose of this policy is to provide human rights for citizens to have a clean, healthy and safe environment. The government's obligation to protect the rights of the people is the basis for the birth of the PERDA KTR. Creating programs that support the improvement of people's lives from various sides, including welfare, security, health and so on. The government establishes KTR as a form of protection for the community from the bad effects of cigarette smoke, either directly or indirectly. In certain circumstances, office processing that falls within the scope of KTR can facilitate smoking rooms or areas.

\subsection{Implementation in Enforcement of Local Regulations on Smoking Free Areas}

Implementation is basically an implementation process. Stewart stated that policy implementation is viewed in a broad sense, as a stage of the policy process immediately after the enactment of a law. ${ }^{13}$ Implementation is seen broadly as having the meaning of implementing laws in which various actors, organizations, procedures and techniques work together to carry out policies in an effort to achieve policy objectives or programs. Salusu in Ingan states that implementation is a set of activities carried out following a decision. A decision is always intended to achieve that goal, it takes a series of activities. So, it can be said that implementation is the operation of various activities in order to achieve certain goals. ${ }^{14}$

\footnotetext{
${ }^{11}$ Sudarto. (1983). Hukum Pidana dan Perkembangan Masyarakat. Bandung: Sinar Baru. p. 20

12 Arief, Barda Nawawi. (2002). Bunga Rampai Kebijakan Hukum Pidana. Bandung: Citra Aditya Bakti. p. 25

${ }^{13}$ Winarno, Budi. (2014). Kebijakan Publik: Teori, Proses, dan Studi Kasus. Yogyakarta: CAPS. P.147

14 Ingan, Falentina Agun. 2016. 'Implementation of Governor Regulation Number 1 of 2013

concerning No Smoking Areas (Case Study at the Abdul Wahab Sjahranie Regional General Hospital
} 
Policy implementation is a way to achieve a goal in a policy, in policy implementation there are four factors or variables that influence the success or failure of policy implementation. The four factors are communication, resources, disposition, and bureaucratic structure. Communication is the first important factor in policy implementation, communication aims to provide information from the authorities to the policy implementers about the intent of policy implementation. ${ }^{15}$

The legal basis that regulates smoke-free areas, in particular is the Regional Regulation concerning No Smoking Areas (KTR). In this regulation, every citizen/community has the responsibility and obligation to respect the rights of others. Through this policy the local government regulates its citizens to live healthy, by protecting the environment from pollution and respecting the rights of others from air pollution. Because basically everyone has the right to have a healthy environment, both physically and spiritually (from the social side). Then from that, every citizen is responsible for creating a healthy life and making it happen, advancing their health, and maintaining health, including the environment. With a healthy, clean and maintained environment, a healthy life can be created.

In making a smoke-free area policy, the City DPRD hopes that the existence of a smoke-free zone policy set out in the Perda is not just made, but has no power in its implementation.

Implementation in the enforcement of local regulations on smoking-free areas is still not optimal, as seen from the previous discussion, there are still individuals or employees who have not complied with the regional regulations for non-smoking areas, which means that there are still employees who smoke arbitrarily in smoking-free areas and there are still employees who do not know there is a smoking place or area called the gazebo building because of the lack of communication between the employees.

According to the author, Implementation in Enforcement of Regional Regulations on Smoking-Free Areas is analyzed with law enforcement theory that law enforcement embodies values or principles that contain justice and truth, law enforcement is not only the task of law enforcers who are known conventionally. , but it is everyone's job. However, in relation to public law the government is responsible.

\subsection{Obstacles in the Implementation of Enforcement of Regional Regulations on Smoking-Free Areas and Their Solutions}

The ineffectiveness of the implementation of the smoke-free zone policy is suspected to be due to many factors as obstacles. Lack of supervision carried out by the Government is the dominant factor causing the implementation of this smoke-free zone policy not going well. Since the issuance of the Perda on No Smoking Areas (KTR) in 2015 until now, supervision has not been maximal so that

(AWS Hospital) Samarinda City)'. E-Journal of Governmental Science. Samarinda. Universitas Mulawarman. p. 500-514.

15 Abidin, Z., \& Hamzah, A. (2010). Pengantar dalam hukum pidana Indonesia. Yarsif Watampone. P. 43 
the implementation of these regulations has not been effective. Inadequate supervision of implementation In addition, the imposition of sanctions that are still weak and even non-existent for policy implementers who do not implement policies or smokers who violate the provisions of the smoke-free zone policy, is one of the triggers for the Regional Regulation to be ineffective.

There are also obstacles in the implementation of Regional Regulations on No Smoking Areas, including:

- A designated smoking area that is rarely used. The designated smoking room is not functioning or is rarely used because there are still employees who do not know that there is a smoking room.

- Lack of employee awareness of comfort and health. Lack of awareness among employees of the benefits of this no-smoking area regulation so that the surrounding environment is fresh and not contaminated with cigarette smoke.

- There are still employees who have not complied with these regulations. There are employees who have not complied with the smoking-free area regulations, meaning that there are still employees who smoke in the room or in nonsmoking areas.

There are several efforts to overcome obstacles in the implementation of Regional Regulations on No Smoking Areas, including:

- The person in charge again provides outreach on the No Smoking Area Regional Regulation to employees. By carrying out socialization activities carried out by the person in charge so that employees understand better about the established No Smoking Area and also with this socialization, it is likely that employees will listen more than the socialization that has been carried out by the Civil Service Police Unit because this socialization was carried out by their own superiors.

- Provide sanctions in the form of fines. By giving sanctions in the form of fines, employees who violate the Regional Regulations on No Smoking Areas are likely not to commit any more violations because the deterrent has been given sanctions in the form of fines, if the employees still violate the sanctions in the form of fines it should be even greater.

- Improve communication about designated smoking rooms. There are still employees who do not know that there is a special smoking room called Gazebo, therefore the special smoking room is rarely used by employees.

- Raise employees' awareness of the benefits of smoke-free areas. By increasing the awareness of employees so that they know the benefits of the smoke-free area so that employees are more complying with regional regulations for no smoking areas.

\section{Closing}

Criminal Law Policy in Enforcement of Local Regulations on Smoking Areas in the KTR PERDA means that the purpose of this policy is to provide human rights for citizens to obtain a clean, healthy and safe environment. The government's obligation to protect people's rights is the basis for the birth of the PERDA KTR. Implementation in the Enforcement of Regional Regulations on No Smoking Areas is still not optimal as seen from the previous discussion there are still individuals 
or employees who have not complied with the regional regulations for no smoking areas. Barriers to implementing Regional Regulations on Smoking Free Areas and their solutions include: Barriers: A designated smoking area that is rarely used. Lack of employee awareness of comfort and health. There are still employees who have not complied with these regulations. The solution: The person in charge again provides socialization on the Regional Regulations for No Smoking Areas to employees. Provide sanctions in the form of fines. Improve communication about designated smoking rooms. Raise employees' awareness of the benefits of smokefree areas.

The government should review the technical guidelines for the implementation of this Perda KTR relating to the evaluation of the effectiveness of communication and the applied bureaucratic structure. The government should optimize resources both in quality and quantity as well as provide more adequate infrastructure support capacity to implement the Perda KTR.

\section{References}

\section{Journals}

[1] Ahmad Faqih, Wonosobo Regulation No. 3 of 2014 on Regarding Regional Organizations to Achieve Good Governance, Jurnal Daulat Hukum, Vol 1, No 2 (2018): June 2018, Universitas Islam Sultan Agung

[2] Amin Purnawan, Muhammad Yanuar Ilham, Implementation Of Withdrawal of Retribution Based On Kudus Regency Regulation No. 14 Of 2012 On The Market Services Retribution In Kliwon Market Kudus, Jurnal Daulat Hukum Vol 2, No 2 (2019): June 2019 Universitas Islam Sultan Agung

[3] Ingan, Falentina Agun. 2016. 'Implementation of Governor Regulation Number 1 of 2013 concerning No Smoking Areas (Case Study at the Abdul Wahab Sjahranie Regional General Hospital (AWS Hospital) Samarinda City)'. EJournal of Governmental Science. Samarinda. Mulawarman University. Pp. 500-514.

[4] Iwan Sulistiyo, Widayati, Sri Kusriyah, Implementation of the Principle of Openness in the Process of Forming Regional Regulations in the Context of Regional Autonomy in Kendal Regency, Jurnal of Daulat Hukum Vol. 1. No. March 1, 2018 ISSN: 2614-560X

[5] Rakhmat Bowo Suharto, Amin Syarifudin, "Analysis Juridical Public Participation Formation of Regional Regulation No. 3 of 2017 on The Implementation of The Business Entertainment In Wonosobo Regency," Jurnal Daulat Hukum ,Vol 2, No 1 (2019): March 2019, Unissula

[6] Timbul Mangaratua Simbolon, Gunarto, Umar Ma'ruf, Criminal Law Policy Against the Crime of Defamation or Defamation Through the Internet in Indonesia as Cybercrime, Jurnal Daulat Hukum Vol. 1. No. 1 March 2018 ISSN: 2614-560X, Universitas Islam Sultan Agung

\section{Books}

[1] Abidin, Z., \& Hamzah, A. (2010). Pengantar dalam hukum pidana Indonesia. Yarsif Watampone

[2] Ali, Zainudin. (2009). Metode Penelitian Hukum. Jakarta: Sinar Grafika 
[3] Arief, Barda Nawawi. (2002). Bunga Rampai Kebijakan Hukum Pidana. Bandung: Citra Aditya Bakti

[4] Sofianto, Hufron. (2010). Mengenai Budaya Merokok Bagi Kesehatan. Bogor: Horizon

[5] Sudarto. (1983). Hukum Pidana dan Perkembangan Masyarakat. Bandung: Sinar Baru

[6] Winarno, Budi. (2014). Kebijakan Publik: Teori, Proses, dan Studi Kasus. Yogyakarta: CAPS

\section{Internet}

[1] http://bisnis.tempo.co/read/news/perokok-indonesia-terbanyak-se-asiatenggara; accessed on 25 September 2020 at 15.02 WIB.

[2] https://budi399.wordpress.com/2019/04/01/keb Policy-hukum-pidana/, accessed on 6 October 2020, 19.37 WIB 